\title{
FORMULASI PERJANJIAN PERKAWINAN PASCA PUTUSAN MK NO. 69/PUU-XIII/2015
}

Mambaul Ngadhimah, Lia Noviana, dan Ika Rusdiana*

\section{Abstrak:}

Perjanjian Perkawinan merupakansuatu persetujuan yang dibuat oleh calon suami istri sebelum atau pada saat perkawinan dilangsungkan untuk mengatur akibat-akibat perkawinan terhadap harta kekayaan. Namun, makna perjanjian perkawinan semakin longgar dengan adanya putusan MK No. 69/PUU-XIII/2015 pada tanggal 27 Oktober 2016. Penelitian ini bertujuan untuk mendeskripsikan tentang Formulasi Perjanjian Perkawinan Pasca Putusan MK No. 69/PUU-XIII/2015 ditinjau dari Hukum Islam dan Peraturan Perundang-Undangan di Indonesia. Penelitian ini menggunakan jenis penelitian pustaka dengan sifat penelitian deskriptif analitik dan pendekatan yuridis normatif. Pengumpulan data primer dilakukan dengan teknik dokumentasi dan teknik analisis data dari induktifke deduktif. Hasil penelitian menunjukkan bahwa: (1)Konsep perjanjian perkawinan dalam Hukum Islam merupakan perjanjian yang kuat (mitsaqan ghalidzan), sedangkan dalam UU di Indonesia, perjanjian perkawinan dapat berupa taklik talak dan perjanjian yang lainnya., (2) Eksistensi perjanjian perkawinan pasca putusan MK No. 69/PUU-XIII/2015 merupakan langkah progresif, yaitu dalam rangka menjaga hak-hak asasi manusia dan hak-hak konstitusional warga negara.(3) Adanya formulasi hukum dalam perjanjian perkawinan pasca putusan MK sejalan dengan teori mashlahah mursalah karena merupakan upaya hukum untuk mengikuti perkembangan zaman, dengan syarat dasar pembentukannya memenuhi tiga hal yaitu kemashlahatan bersifat umum, hakiki dan tidak bertentangan dengan nash syar'i ataupun perundang-undangan yang berlaku.

Kata kunci: Perjanjian Perkawinan, Hukum Islam, UndangUndang 


\section{PENDAHULUAN}

Pada dasarnya perkawinan merupakan suatu perjanjian yang kuat, mengikat lahir dan batin dengan dasar iman. ${ }^{1}$ Dalam Kompilasi Hukum Islam (KHI) perjanjian perkawinan dapat dibuat dalam bentuk taklik talak dan perjanjian lain yang tidak bertentangan dengan hukum Islam. ${ }^{2}$ Menurut Undang-Undang Perkawinan No. 1 Th. 1974, perkawinan merupakan sebuah ikatan lahir batin antara seorang pria dengan seorang wanita sebagai suami-istri dengan tujuan membentuk keluarga (rumah tangga) yang bahagia dan kekal berdasarkan Ketuhanan Yang Maha Esa. ${ }^{3}$

Al-Qur'an menyebut perkawinan sebagai perjanjian yang kokoh, mitsaqan ghalidzan, seperti yang termaktub dalam Surat An-Nisaa ayat 21 :

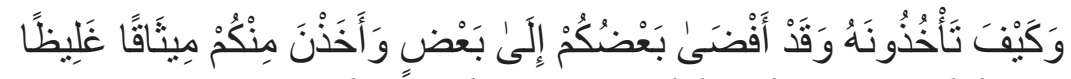

Artinya: Bagaimana kamu akan mengambil mahar yang telah kamu berikan kepada isterimu, padahal sebagian kamu telah bergaul dengan sebagian yang lain sebagai suami isteri. Dan mereka (isteri-isterimu) telah mengambil dari kamu perjanjian yang kuat. (QS. An-Nisa: 21)

Umumnya perjanjian perkawinan di Indonesia ini dibuat manakala terdapat harta kekayaan yang lebih besar pada suatu pihak daripada pihak lain. Maksud pembuatan perjanjian perkawinan ini adalah untuk mengadakan penyimpangan terhadap ketentuanketentuan tentang persatuan harta kekayaan. Para pihak bebas menentukan hukum yang dikehendakinya atas harta kekayaan yang menjadi obyeknya. ${ }^{4}$

Namun, makna perjanjian perkawinan semakin longgar dengan adanya putusan MK Nomor 69/PUU-XIII/2015 pada tanggal 27 Oktober 2016, yang mana isinya mengabulkan permohonan uji materi terhadap ketentuan mengenai Perjanjian Perkawinan yang diatur dalam Pasal 29 ayat (1), ayat (3) dan ayat (4) UU No. 1 Tahun 1974 tentang Perkawinan. Dengan putusan MK itu, kini perjanjian tak

${ }^{1}$ Wirjono Prodjodikoro, Hukum Perkawinan di Indonesia (Sumur Bandung, Jakarta, 1981) hlm. 8.

${ }^{2}$ Inpres No. 1 Tahun 1991 tentang Kompilasi Hukum Islam (KHI)

${ }^{3}$ Undang-Undang No. 1 Th. 1974 Tentang Perkawinan, dalam Pasal 1

${ }^{4}$ Damanhuri, Segi-Segi Hukum Perjanjian Perkawinan Harta Bersama (Bandung: Mandar Maju, 2007), 14. 
lagi bermakna perjanjian yang dibuat sebelum perkawinan (prenuptial agreement) tetapi juga bisa dibuat setelah perkawinan berlangsung. ${ }^{5}$

Mahkamah Konstitusi mengabulkan secara bersyarat permohonan Ike Farida, seorang warga negara Indonesia yang menikah dengan warga negara Jepang. Mahkamah memberi tafsir konstitusional terhadap Pasal 29 ayat (1), ayat (3), dan ayat (4) UU No. 1 Tahun 1974 tentang Perkawinan. Kini, pembuatan perjanjian perkawinan bisa disesuaikan dengan kebutuhan hukum masing-masing pasangan. ${ }^{6}$

Di satu sisi putusan $\mathrm{MK}$ adalah buah dari pemikiran maju dan Hakim mengikuti perkembangan hukum, sosial, dan budaya. Pemikiran yang dituangkan ke dalam putusan itu bertujuan untuk melindungi hak-hak dan kepentingan para pihak dalam perkawinan. Sehingga adanya kepastian hukum dan perlindungan hukum bagi pasangan yang terikat suatu hubungan.

Namun di sisi lain, putusan ini bisa dinilai sebagai putusan yang memperlakukan pernikahan lebih sebagai hubungan kontraktual atau hubungan perdata biasa sebagaimana lembaga perkawinan umumnya diperlakukan di dunia Barat. Di Indonesia, perkawinan umumnya dianggap sebagai ikatan yang bersifat sakral dalam ikatan lahir batin antara laki-laki dan perempuan yang di atur dalam agama.

Maka dengan ini, peneliti ingin membahas lebih lanjut mengenai Formulasi Perjanjian Perkawinan Pasca Putusan MK No. 69/PUU. XIII/2015 ditinjau dari Hukum Islam dan Peraturan PerundangUndangan di Indonesia.

${ }^{5}$ http://www.hukumonline.com/berita/baca/lt58180e2811d66/plus-minus-putusanmk-tentang-perjanjian-perkawinan, diakses pada 20 April 2017.

${ }^{6}$ Putusan MK ini menciptakan suatu norma hukum baru terkait Perjanjian Perkawinan khususnya merubah pasal 29 UU No. 1 Tahun 1974 tentang Perkawinan sebagai berikut:

(1) Pada waktu, sebelum dilangsungkan atau selama dalam ikatan perkawinan kedua belah pihak atas persetujuan bersama dapat mengajukan perjanjian tertulis yang disahkan oleh pegawai pencatat perkawinan atau notaris, setelah mana isinya berlaku juga terhadap pihak ketiga sepanjang pihak ketiga tersangkut.

(2) Perjanjian tersebut tidak dapat disahkan bilamana melanggar batas-batas hukum, agama dan kesusilaan.

(3) Perjanjian tersebut berlaku sejak perkawinan dilangsungkan, kecuali ditentukan lain dalam Perjanjian Perkawinan.

(4) Selama perkawinan berlangsung, perjanjian perkawinan dapat mengenai harta perkawinan atau perjanjian lainnya, tidak dapat diubah atau dicabut, kecuali bila dari kedua belah pihak ada persetujuan untuk mengubah atau mencabut, dan perubahan atau pencabutan itu tidak merugikan pihak ketiga. 


\section{PEMBAHASAN}

\section{Konsep Perjanjian Perkawinan dalam Hukum Islam}

Perkawinan adalah sunatullah yang berlaku bagi semua umat manusia guna melangsungkan hidupnya dan untuk membentuk rumah tangga. Karena rumah tangga adalah bangunan yang paling vital dalam pembentukan struktur sosial masyarakat dan umat secara keseluruhan, ${ }^{7}$ maka agama Islam sangat menganjurkan perkawinan. Serta bagi masyarakat Indonesia perkawinan merupakan suatu yang sakral, suci, bukanlah merupakan peristiwa yang kecil.

Sedangkan dalam Pasal 2 Kompilasi Hukum Islam (KHI) bahwa perkawinan menurut hukum Islam adalah pernikahan, yaitu akad yang kuat atau mitsaqan ghalidzan untuk mentaati perintah Allah dan melakukannya merupakan ibadah. Serta perkawinan bertujuan untuk mewujudkan kehidupan rumah tangga yang sakinah, mawaddah dan rohmah. Menurut Ja'far Muhammad bin Jarir Ath-Thabari dalam tafsirnya mengatakan. Takwil firman Allah وأخذن منكم ميثاقا غليظا: "Dan mereka (istri-istrimu) telah mengambil dari kamu perjanjian yang kuat." Ja'far berkata: maknyanya adalah, "Apa yang kalian tetapkan, berupa perjanjian damikrar kalian kepada merekauntuk memperlakukan mereka dengan baik, atau menceraikannya dengan baik." ${ }^{8}$

Menurut M. Shahrur perjanjian perkawinan (mitsaqaz-zaujiyyah) dalam at-Tanzil al-Hakim terdapat dalam firman Allah Swt, surat An-Nisa ayat 20-21 menyatakanbahwa dalam perkawinan terdapat sebuah perjanjian yang kuat diambil oleh para istri dari para suami mereka, dan tidak terdapat dalam posisi milk al-yamin. ${ }^{9}$

Dalam Al-Qur'an, setidaknya ada 2 (dua) yang berkaitan dengan perjanjian, yaitu kata akad (al-'aqdu) dan kata 'ahd (al'ahdu). Kata yang disebutkan pertama, secara etimologis memiliki makna perjanjian, perikatan, dan pemufakatan (al-ittifaq). AlQur'an memakai kata ini dalam arti perikatan perjanjian. Hal ini dapat dilihat dalam QS. Al-Maidah: $1 .^{10}$

7Syaikh Mahmud al-Mashri, Bekal Pernikahan (Jakarta: Qisthi Perss, 2011), 44.

${ }^{8}$ Tafsir Ath-Thabari, Penerjemah, Akhmad Affandi (Jakarta: Pustaka AZZAM, 2008), 661-664.

${ }^{9}$ Muhammad Shahrur, Metodologi Fiqih Islam Kontemporer (Yogyakarta: eLSAQ Press, Cet II, 2004), 439.

${ }^{10}$ Wahbah Zuhaili, al-Fiqh al-Islamy wa Adillatuh (Mesir: Dar al-Fikr, Jilid IV. Cet. III, 1989), 80-81. 


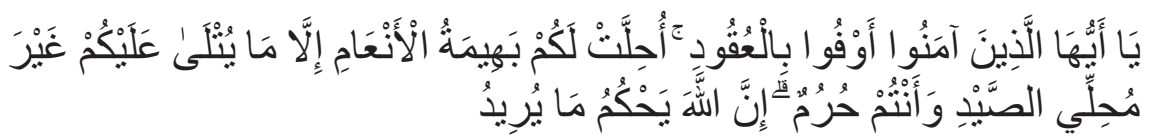

Artinya: Hai orang-orang yang beriman, penuhilah aqad-aqad itu. dihalalkan bagimu binatang ternak, kecuali yang akan dibacakan kepadamu. (yang demikian itu) dengan tidak menghalalkan berburu ketika kamu sedang mengerjakan haji. Sesungguhnya Allah menetapkan hukum-hukum menurut yang dikehendaki-Nya. (QS. Al-Maidah ayat 1) ${ }^{11}$

Sedangkan kata al-'ahdu, secara etimologis berarti masa, pesan, penyempurnaan dan janji atau perjanjian. Hal ini dapat dilihat dalam Al-Qur'an surat An-Nahl ayat 91 dan Al-Isra ayat 34.

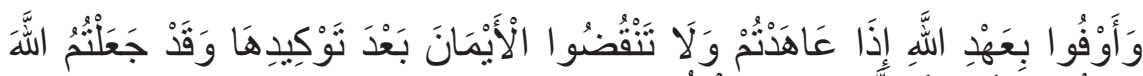

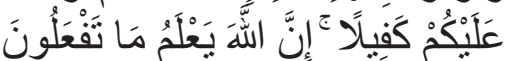

Dan tepatilah perjanjian dengan Allah apabila kamu berjanji dan janganlah kamu membatalkan sumpah-sumpah (mu) itu, sesudah meneguhkannya, sedang kamu Telah menjadikan Allah sebagai saksimu (terhadap sumpah-sumpahmu itu). Sesungguhnya Allah mengetahui apa yang kamu perbuat. (Qs. An-Nahl ayat 91) ${ }^{12}$

Berkaitan dengan ruang lingkup perjanjian ini Ibn Araby mengemukakan pendapatnya, ada 5 (lima) hal yang termasuk dalam kategori perjanjian, yakni;

a. Perjanjian secara umum.

b. Sumpah.

c. Kewajiban yang telah dibebankan Allah kepada hambanya.

d. Akad Nikah, perkongsian (syirkah), jual beli, sumpah dan janji kepada Allah.

e. Perikatan atas dasar saling mempercayai. ${ }^{13}$

Adapun syarat-syarat perjanjian dalam Islam:

a. Tidak menyalahi hukum syariat, Rasulullah Saw, bersabda: ${ }^{14}$

${ }^{11} \mathrm{Ibid}, \mathrm{1} 156$.

${ }^{12} \mathrm{Ibid}, .416$.

${ }^{13}$ Abu Zakariya Muhammad ibn Abdullah Ibn Araby, tt, Ahkam al-Qu'an (Beirut: Dar al-Ma'rifah, Juz II), 524-525.

${ }^{14}$ Fiqih Sunnah, Penerjemah Nor Hasanuddin (Jakarta: Pena Pundi Aksara, cet. I, 2006), 83. 


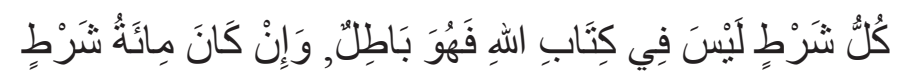

"Segala bentuk persyaratan yang tidak ada dalam kitab Allah adalah batil, sekalipun ia terdiri dari seratus syarat."

b. Harus sama-sama ridha dan berdasarkan pada kesepakatan bersama. Karena tidak ada penghargaan terhadap akad yang menafikan kebebasan seseorang.

c. Harus jelas tidak samar sehingga tidak mengundang berbagai interpretasi yang menimbulkan salah paham pada waktu penerapannya.

Selain syarat-syarat tersebut, perjanjian dalam hukum Islam harus sesuai dengan asas-asas yang berlaku. Asas ini berpengaruh pada status akad. Ketika akad ini tidak terpenuhi, maka akan mengakibatkan batal atau tidak sahnya perikatan/perjanjian yang dibuat. Adapun asas-asas tersebut adalah: ${ }^{15}$
a. Asas Ibahah (Mabda' al-Ibahah) ${ }^{16}$
b. Asas kebebasan berakad (Mabda' Hurriyyah at- Ta'aqud) ${ }^{17}$
c. Asas Konsensualisme (Mabda' ar-Radha'iyyah) ${ }^{18}$
d. Asas Janji itu mengikat ${ }^{19}$

\footnotetext{
${ }^{15}$ Gemala Dewi dkk, Hukum Perikatan Islam di Indonesia (Jakarta: Kencana, 2006), $30-31$.

${ }^{16}$ Asas ibahah adalah asas umum hukum Islam dalam bidang muamalah secara umum. Asas ini dirumuskan dengan dalil "pada dasarnya sesuatu itu boleh dilakukan sampai ada dalil yang melarangnya." Bila dikaitkan dengan tindakan hukum, khususnya perjanjian, maka ini berarti bahwa tindakan hukum dan perjanjian apa pun dapat dibuat sejauh tidak ada larangan khusus mengenai perjanjian tersebut. Lihat Syamsul Anwar, Hukum Perjanjian Syariah Studi Teori akad dalam Fikih Muamalah (Jakarta: PT Raja Grafindo Persada, 2010), 84.

${ }^{17}$ Hukum Islam mengakui kebebasan berakad, yaitu prinsip hukum yang menyatakan bahwa setiap orang dapat membuat akad jenis apapun sesuai dengan kepentingannya sejauh tidak berakibat makan harta sesama dengan jalan batil. Kebebasan membuat akad dalam hukum Islam tidaklah mutlak, melainkan dibatasi. Dalam hukum Islam, pembatasan itu dikaitkan dengan "larangan makan harta sesama dengan jalan batil" sebagai mana dalam QS. An-Nisa: 49. Lihat Dahlan Tamrin, Filsafat Hukum Islam (Malang: UIN-malang Press, 2007), 99.

${ }^{18}$ Asas konsensualisme menyatakan bahwa untuk terciptanya suatu perjanjian cukup dengan tercapainya kata sepakat antara para pihak tanpa perlu dipenuhinya formalitasformalitas tertentu.

${ }^{19}$ Dalam Al-Qur'an dan hadist terdapat banyak perintah agar memenuhi janji. Dalam kaidah usul fiqih, "perintah itu pada dasarnya menunjukkan wajib". Ini berarti bahwa janji itu mengikat dan wajib dipenuhi.
} 

e. Asas keseimbangan (Mabda' at-Tawazun fi al-Mu'awadhah $)^{20}$
f. Asas Tidak Memberatkan (Kemaslahatan) ${ }^{21}$
g. Asas Keadilan (Al-'Adalah) ${ }^{22}$
h. Asas Kejujuran dan kebenaran (Ash-Shidq) ${ }^{23}$
i. Asas Tertulis (Al-Kitabah) ${ }^{24}$

\section{Konsep Perjanjian Perkawinan dalam Peraturan Perundang- Undangan di Indonesia}

Dalam Undang-Undang No. 1 Th. 1974 tentang Perkawinan Pasal 29 dijelaskan bahwa pada waktu atau sebelum perkawinan dilangsungkan, kedua pihak atas persetujuan bersama dapat mengadakan perjanjian tertulis yang disahkan oleh Pegawai pencatat perkawinan, setelah mana isinya berlaku juga terhadap pihak ketiga sepanjang pihak ketiga tersangkut. Perjanjian tersebut tidak dapat disahkan bilamana melanggar batas-batas hukum, agama dan kesusilaan.

${ }^{20}$ Dalam hukum Islam sangat menekankan perlunya keseimbangan itu, baik keseimbangan antara apa yang diberikan dan apa yang diterima maupun keseimbangan dalam memikul resiko. Asas keseimbangan dalam transaksi (antara apa yang diberikan dan apa yang diterima) tercermin pada dibatalkannya suatu akad yang mengalami ketidakseimbangan prestasi yang mencolok. Asas keseimbangan dalam memikul risiko tercermin dalam larangan terhadap transaksi riba.

${ }^{21}$ Dengan asas kemaslahatan dimaksud bahwa akad yang dibuat oleh para pihak bertujuan untuk mewujudkan kemaslahatan bagi mereka dan tidak boleh meinimbulkan kerugian (mudharat) atau keadaan memberatkan (masyaqqah). Apabila dalam pelaksanaan akad terjadi suatu perubahan keadaan yang tidak dapat diketahui sebelumnya serta membawa kerugian yang fatal bagi pihak bersangkutan sehingga memberatkannya, maka kewajibannya dapat diubah dan disesuaikan kepada batass yang masuk akal.

${ }^{22}$ Keadilan adalah salah satu sifat Tuhan dan Al-Qur'an menekankan agar manusia menjadikannya sebagai ideal moral. Allah menerangkan tentang keadilan, dalam Al-Qur'an surat Al-A'raf: 29, An-Nahl: 90 dan As-Syura: 15.

${ }^{23}$ Kejujuran adalah nilai etika yang mendasar dalam Islam. Islam adalah nama lain dari kebenaran (QS. 3:95). Allah berbicara benar dan memerintahkan semua muslim untuk jujur dalam segala urusan dan perikatan (QS. 33:70). Islam dengan tegas melarang kebohongan dan penipuan dalam bentuk apa pun. Pada asas ini tidak dijalankan, maka akan merusak legalitas akad yang dibuat

${ }^{24}$ Prinsip lain yang tidak kalah pentingnya dalam melakukan akad sebagaimana disebutkan dalam Al-Qur'an surat Al-Baqarah: 282-283. Ayat ini mengisyaratkan agar akad yang dilakukan benar-benar berada dalam kebaikan bagi semua pihak yang melakukan akad, maka akad itu hatus dilakukan dengan melakukan kitabah. Di samping itu, juga diperlukan adanya saksi-saksi (syahadah) dan prinsip tanggung jawab. 
Perjanjian perkawinan menurut Pasal 29 ayat (2) UndangUndang No. 1 Th. 1974, adalah perjanjian tersebut tidak dapat disahkan jika isinya bertentangan dengan kesusilaan, undangundang atau ketertiban umum. ${ }^{25}$ Perjanjian tersebut harus dibuat secara tertulis dan disahkan oleh pegawai pencatat perkawinan pada waktu atau sebelum perkawinan. Ayat (4) dari Pasal 29 tersebut lebih lanjut menyatakan bahwa selama perkawinan berlangsung perjanjian tersebut tidak dapat diubah, kecuali bila dari kedua belah pihak ada persetujuan untuk merubahnya dan perubahan itu tidak merugikan pihak ketiga.

Akta notaris dalam perjanjian perkawinan tidak semata-mata dimaksudkan sebagai alat pembuktian saja akan tetapi lebih dari itu akta notaris dimaksudkan agar:

a. Perjanjian perkawinan tersebut dituangkan dalam bentuk akta otentik yang mempunyai kekuatan pembuktian yang kuat.

b. Memiliki kepastian hukum mengenai hak dan kewajiban suami isteri atas harta benda mereka

c. Mencegah kemungkinan adanya penyelundupan hukum atas ketentuan Pasal 144 Kitab Undang-Undang Hukum Perdata yang menyatakan bahwa perjanjian perkawinan tidak boleh diubah dengan cara apapun setelah perkawinan berlangsung.

d. Untuk mencegah perbuatan tergesa-gesa dari para pihak, serta untuk memikirkan perbuatan hukum yang dilakukannya. Hal ini mengingat perjanjian perkawinan mempunyai akibat atas harta kekayaan suami isteri dalam jangka waktu yang lama atau sepanjang perkawinan. ${ }^{26}$

Pada Kompilasi Hukum Islam mengenai perjanjian perkawinan diatur pada Bab VII pasal 45 sampai 52 tentang perjanjian perkawinan. pasal 45 Kompilasi Hukum Islam (KHI) menyatakan bahwa "Kedua calon mempelai dapat mengadakan perjanjian perkawinan dalam bentuk:

a. Taklik talak.

b. Perjanjian lain yang tidak bertentangan dengan hukum Islam.

Apabila perjanjian yang telah disepakati bersama antara suami dan isteri, tidak dipenuhi oleh salah satu pihak, maka pihak lain

${ }^{25} \mathrm{Ibid}, .46$.

${ }^{26} \mathrm{R}$, Soetojo Prawirohamidjojo., Hukum Perikatan, 45. 
berhak untuk mengajukan persoalannya ke Pengadilan Agama untuk menyelesaikannya. Dalam hal pelanggaran dilakukan suami misalnya isteri berhak meminta pembatalan nikah atau sebagai alasan perceraian dalam gugatannya. Demikian juga sebaliknya jika si isteri yang melanggar perjanjian di luar taklik talak, suami berhak mengajukan perkaranya ke Pengadilan Agama. ${ }^{27}$

Sementara jika dilihat penggunaannya, seperti dalam praktek di Indonesia, taklik talak adalah terjadinya talak (perceraian) atau perpisahan antara suami dan istri yang digantungkan kepada sesuatu, dan sesuatu ini dibuat dan disepakati pada waktu dilakukan akad nikah. Maka pelanggaran terhadap apa yang disepakati inilah yang menjadi dasar terjadinya perceraian (talak) atau perpisahan. Berdasarkan substansi inilah menjadi dasar untuk mengatakan bahwa taklik talak pada prinsipnya sama dengan perjanjian perkawinan yang dapat menjadi dasar dan alasan terjadinya perceraian atau perpisahan antara suami dan isteri. Misalnya dalam buku nikah Indonesia, shigat taklik, berisi perjanjian perkawinan. ${ }^{28}$

Di dalam peraturan Menteri Agama Nomor 3 Tahun 1975 Pasal 11 menyebutkan:

a. Calon suami isteri dapat mengadakan perjanjian sepanjang tidak bertentangan dengan hukum Islam.

b. Perjanjian yang berupa taklik talak dianggap sah kalau perjanjian itu diucapkan dan ditandatangani oleh suami setelah akad nikah dilangsungkan.

c. Sighat taklik talak ditentukan oleh Menteri Agama.

\footnotetext{
${ }^{27}$ Ahmad Rofiq, Hukum Islam di Indonesia (Jakarta: Raja Grafindo Persada, 2003), 162.

${ }^{28}$ Menurut Kholil Rahman terdapat macam-macam sifat perjanjian, yaitu:
}

a. Syarat-syarat yang menguntungkan isteri, seperti syarat untuk tidak dimadu. Para ulama berbeda pendapat dalam masalah ini ada yang mengatakan sah dan ada yang mengatakan tidak sah.

b. Syarat-syarat yang bertentangan dengan apa yang dikehendaki oleh maksud akad itu sendiri. Seperti tidak boleh mengadakan hubungan kelamin, tidak ada hak waris di antara suami isteri, tidak boleh berkunjung kepada kedua orang tua, dan lain-lain. Syarat-syarat semacam itu tidak sah dan tidak mengikat.

c. Syarat-syarat yang bertentangan dengan ketentuan syara', seperti jika akad nikah sudah dilangsungkan, agar masing-masing pindah agama, harus makan daging babi, dan sebagainya. Perjanjian semacam ini tidak sah, dan bahkan akad nikahnya juga tidak sah. Lihat Sayid Sabiq, Figh Sunnah (Beirut: Dar al-Fikr, Juz II, 1983), 114. 
Adapun syarat-syarat perjanjian diatur dalam KUHPerdata pasal 1320. Ketentuan tersebut mengatur tentang syarat yang harus dipenuhi dalam pembuatan perjanjian perkawinan. ${ }^{29}$ Syarat-syarat tersebut adalah sebagai berikut:

a. Adanya kata sepakat. ${ }^{30}$

b. Adanya kecakapan untuk mengikatkan diri. ${ }^{31}$

c. Adanya hal tertentu (yang menjadi dasar dari perjanjian). ${ }^{32}$

d. Adanya sebab yang halal. ${ }^{33}$

Adapun asas-asas perjanjian yang dikenal dalam hukum perdata antara lain adalah:

a. Asas pacta sun servanda. ${ }^{34}$

${ }^{29}$ H.F.A.Vollmar, Hukum Keluarga Menurut Kitab Undang-Undang Hukum Perdata (Bandung: Tarsito, 1982), 59.

${ }^{30}$ Kesepakatan para pihak dalam perjanjian mengandung para pihak, sepakat atau ada kesesuaian kehendak untuk mengikatkan diri tanpa ada paksaan dari pihak lain (dwang), tidak ada unsur kekhilafan (dwaling), serta tidak ada penipuan (bedrog), jika tidak maka kesepakatan itu menjadi tidak sah dan perjanjian yang dibuat menjadi perjanjian yang cacat (defective agreement).Perjanjian perkawinan yang dibuat oleh calon suami isteri harus lahir dari kesepakatan calon suami isteri sendiri dan bukan atas paksaan orang lain, kekhilafan atau kealpaan salah satu pihak. Lihat I.G Rai Widjaya, Merancang Suatu Kontrak (Bekasi: Megapoint, 2004), 47.

${ }^{31}$ Para pihak dalam perjanjian suatu harus mempunyai kewenangan untuk melakukan perbuatan hukum. Di antara syarat ini yang harus dipenuhi adalah para pihak dalam keadaan telah dewasa dan tidak sedang berada dalam pengampuan. Yaitu harus dewasa atau berumur minimal 21 tahun (Pasal 1330 KUHPerdata). Dalam hal ini undang- undang beranggapan bahwa setiap orang adalah cakap untuk membuat perikatan (perjanjian) apabila ia oleh Undang-Undang tidak dinyatakan tidak cakap. Lihat I.G Rai Widjaya, Merancang Suatu Kontrak, 48.

${ }^{32}$ Dalam syarat ketiga ini. Undang-Undang menentukan bahwa yang dijadikan obyek (voorwerp) atau prestasi harus benar-benar mungkin dan dapat dilaksanakan. Jika prestasinya merupakan sesuatu yang secara obyektif atau mutlak tidak mungkin dapat dilaksanakan, maka perjanjian itu tidak mempunyai kekuatan mengikat karena tidak ada kewajiban untuk melakukan sesuatu yang tidak mungkin untuk dikerjakan.

${ }^{33}$ Syarat keempat untuk sahnya perjanjian adalah sebab yang halal (oorzaak). Kausa yang diperbolehkan dalam hal ini selain sebagaimana diperbolehkan oleh Undang-Undang, juga tidak boleh bertentangan dengan ketertiban umum (openbare orde/ public policy) dan atau kesusilaan (zeden/morality). Sebab yang halal berfungsi sebagai alat atau upaya untuk melindungi kepentingan para pihak atau pihak ketiga. Lihat Soetojo Prawirohamidjojo, Marthlmena Pohan, Hukum Perikatan (Surabaya: PT Bina Ilmu, 1984), 167.

${ }^{34}$ Perjanjian yang dibuat secara sah berlaku sebagai UU, sesuai dengan pasal 1338 ayat (1) KUHPdt yang berbunyi :"Semua persetujuan yang dibuat secara sah berlaku sebagai UU bagi mereka yang membuatnya". Lihat Mariam Darus Badrulzaman, Kompilasi Hukum Perikatan (PT Citra Aditya Bakti, 2001), 82. 


\author{
b. Asas konsensualisme. ${ }^{35}$ \\ c. Asas kebebasan berkontrak. ${ }^{36}$ \\ d. Asas kepercayaan. ${ }^{37}$ \\ e. Asas kekuatan mengikat. ${ }^{38}$ \\ f. Asas persamaan hukum. ${ }^{39}$ \\ g. Asas keseimbangan. ${ }^{40}$ \\ h. Asas Kepastian Hukum. ${ }^{41}$ \\ i. Asas moral. ${ }^{42}$ \\ j. Asas kepatutan. ${ }^{43}$
}

${ }^{35}$ Yaitu pada dasarnya perjanjian dan perikatan yang timbul karenanya itu sudah dilahirkan sejak detik tercapainya kesepakatan. Dengan kata lain perjanjian itu sudah sah apabila sudah sepakat mengenai hal-hal yang pokok dan tidaklah diperlukan sesuatu formalitas. Asas konsensualisme terdapat dalam Pasal 1320 KUHPdt.

${ }^{36}$ Sebagaimana disebutkan dalam pasal 1320 KUHPdt yaitu bahwa setiap orang bebas membuat perjanjian sepanjang prestasi yang dilakukan tidak dilarang.Mengenai sebab yang dilarang disebutkan dalam Pasal 1337 Kitab Undang-Undang Hukum Perdata yang berbunyi: "Suatu sebab adalah terlarang apabila dilarang oleh undang-undang atau apabila berlawanan dengan kesusilaan atau ketertiban umum". Lihat Kartini Mulyadi, Gunawan Widjaja, Perikatan Yang Lahir Dari Perjanjian (Jakarta: Raja Grafindo Persada, 2003), 46.

${ }^{37}$ Seseorang yang melakukan perjanjian dengan pihak lain berarti menumbuhkan kepercayaan di antara kedua pihak itu, bahwa satu sama lain akan memegang janjinya atau dengan kata lain akan memenuhi prestasi di belakang hari.

${ }^{38}$ Perjanjian mempunyai kekuatan mengikat para pihak. Terikatnya para pihak dalam perjanjian tidak semata terbatas pada apa yang diperjanjikan, namun juga terhadap beberapa unsur lain sepanjang dikehendaki oleh kebiasaan, kepatutan dan moral. Hal ini, merupakan implementasi asas Pacta Sun Servanda yang terdapat dalam Pasal 1338 ayat (1) KUHPerdata, menyatakan bahwa perjanjian yang dibuat secara sah berlaku sebagai undang-undang.

${ }^{39}$ Yaitu menempatkan para pihak dalam perjanjian sama derajatnya dan tidak terdapat perbedaan derajat apapun. Oleh karena terdapat persamaan, maka masing-masing pihak diharuskan menghormati satu sama lainnya.

${ }^{40}$ Yaitu menghendaki kedua pihak memenuhi dan melaksanakan perjanjian dengan baik.

${ }^{41}$ Perjanjian sebagai sebuah UU harus mengandung kepastian hukum. Kepastian hukum dalam perjanjian dapat disimak dari kekuatan mengikatnya perjanjian yaitu sebagai undang-undang bagi para pihak.

${ }^{42}$ Artinya suatu perbuatan sukarela dari seseorang tidak akan menimbulkan hak apapun bagi orang tersebut untuk menuntut prestasi dari pihak lainnya. Namun demikian seseorang yang melakukannya dengan sekarela tersebut justru mempunyai kewajiban untuk meneruskan dan menyelesaikan perbuatan itu dengan baik.

${ }^{43}$ Hubungan hukum antara para pihak dalam bentuk perjanjian harus memperhatikan rasa keadilan masyarakat. 


\section{Implementasi Perjanjian Perkawinan Pasca Putusan MK No. 69/ PUU-XIII/2015}

Empat puluh tiga tahun pasca diundangkannya Undang-Undang No. 1 Tahun 1974 Tentang Perkawinan khususnya dalam pengaturan Perjanjian Perkawinan pada Pasal 29 UU No. 1 Th. 1974 tentang Perkawinan, Pasal a quo, diujikan materi ke Mahkamah Konstitusi. Pengujian materi ini diajukan oleh Ike Farida dengan Nomor Putusan 69/PUU-XIII/2015.Atas pengujian ini, Mahkamah Konstitusi memberikan putusan untuk mengabulkan sebagian. ${ }^{44}$

Maka setelah Putusan MK No. 69/PUU-XIII/2015 pasal 29 UU No. 1 Th. 1974 menjadi:

1. Pada waktu, sebelum dilangsungkan atau selama dalam ikatan perkawinan kedua belah pihak atas persetujuan bersama dapat mengajukan perjanjian tertulis yang disahkan oleh pegawai pencatat perkawinan atau notaris, setelah mana isinya berlaku juga terhadap pihak ketiga sepanjang pihak ketiga tersangkut.

2. Perjanjian tersebut tidak dapat disahkan bilamana melanggar batas-batas hukum, agama dan kesusilaan.

3. Perjanjian tersebut berlaku sejak perkawinan dilangsungkan, kecuali ditentukan lain dalam Perjanjian Perkawinan.

4. Selama perkawinan berlangsung, perjanjian perkawinan dapat mengenai harta perkawinan atau perjanjian lainnya, tidak dapat diubah atau dicabut, kecuali bila dari kedua belah pihak ada

${ }^{44}$ Mahkamah Konstitusi memberikan putusan inkonstitusional bersyarat bahwa:

1. Pasal 29 ayat (1) Undang-Undang No. 1 Tahun 1974 Tentang Perkawinan bertentangan dengan UUD 1945 dan tidak memiliki kekuatan hukum mengikat sepanjang tidak dimaknai "Pada waktu, sebelum dilangsungkan atau selama dalam ikatan perkawinan kedua belah pihak atas persetujuan bersama dapat mengajukan perjanjian tertulis yang disahkan oleh pegawai pencatat perkawinan atau notaris, setelah mana isinya berlaku juga terhadap pihak ketiga sepanjang pihak ketiga tersangkut.

2. Pasal 29 ayat (3) Undang-Undang No. 1 Tahun 1974 Tentang Perkawinan bertentangan dengan UUD 1945 dan tidak memiliki kekuatan hukum mengikat sepanjang tidak dimaknai "perjanjian tersebut mulai berlaku sejak perkawinan dilangsungkan, kecuali ditentukan lain dalam perjanjian perkawinan.

3. Pasal 29 ayat (4) Undang-Undang No. 1 Tahun 1974 Tentang Perkawinan bertentangan dengan UUD 1945 dan tidak memiliki kekuatan hukum mengikat sepanjang tidak dimaknai selama perkawinan berlangsung, perjanjian perkawinan dapat mengenai harta perkawinan atau perjanjian lainnya, tidak dapat diubah atau dicabut, kecuali bila dari kedua belah pihak ada persetujuan untuk mengubah atau mencabut, dan perubahan atau pencabutan itu tidak merugikan pihak ketiga. 
persetujuan untuk mengubah atau mencabut, dan perubahan atau pencabutan itu tidak merugikan pihak ketiga.

Dasar dan prinsip utama dalam sebuah perjanjian adalah kebebasan berkontrak (freedom of contract) sebagaimana diatur dalam Pasal 1338 ayat (1) KUH Perdata, yang mengatur:

"Semua perjanjian yang dibuat secara sah berlaku sebagai undang-undang bagi mereka yang membuatnya";

Asas ini merupakan suatu asas yang memberikan kebebasan kepada para pihak untuk:

1. membuat atau tidak membuatperjanjian;

2. mengadakan perjanjian dengansiapapun;

3. menentukan isi perjanjian, pelaksanaan dan persyaratannya,serta;

4. menentukan bentuk perjanjiannya apakah tertulis ataulisan;

Hal ini diperkuat oleh Pasal 28E ayat (2) UUD 1945 yang mengatur setiap orang berhak atas kebebasan meyakini kepercayaan, menyatakan pikiran dan sikap, sesuai dengan hati nuraninya, termasuk menuangkannya kedalam suatu pernyataan dan perjanjian yang isinya dituangkan sesuai dengan pikiran dan hatinuraninya. Begitu juga diatur dalam pasal 1338 ayat (3) KUH Perdata tentang asas itikad baik (good faith). ${ }^{45}$

Hal-hal terurai tersebut di atas dapat disimpulkan bahwa setiap orang berhak untuk melakukan Perjanjian dengan siapapun, kapanpun, dengan isi apapun, asal dilaksanakan dengan itikad baik serta tidak bertentangan dengan Undang-Undang, kesusilaan, ataupun ketertiban umum.

Perjanjian perkawinan yang dimaksud dalam pasal 29 UU No. 1 Th. 1974 adalah selain dari taklik talak. Taklik talak (talak yang digantungkan) sebagaimana telah diketahui adalah janji suami terhadap istri pada sesaat setelah akad nikah berlangsung.

${ }^{45}$ Dalam pasal 1338 ayat (3) KUHPerdata ini mengharuskan para pihak untuk melaksanakan substansi kontrak berdasarkan kepercayaan atau keyakinan yang teguh maupun kemauan (itikad) baik dari para pihak. Asas itikad baik terbagi menjadi dua, yakni itikad baik nisbi dan itikad baik mutlak. Pada itikad yang pertama, seseorang memperhatikan sikap dan tingkah laku yang nyata dari subjek. Pada itikad yang kedua, penilaian terletak pada akal sehat dan keadilan serta dibuat ukuran yang objektif untuk menilai keadaan (penilaian tidak memihak) menurut norma-norma yang objektif. 
Menurut Yusuf Al-Qardhawi, talak yang digantungkan itu termasuk sumpah yang dapat diselesaikan dengan kaffarat karena melanggar sumpah. Di Indonesia menurut Kompilasi Hukum Islam Pasal 116 huruf g taklik talak adalah merupakan alasan perceraian yaang diajukan oleh isteri jika "suami melanggar taklik talak. ${ }^{46}$

Menurut Pasal 29 ayat (2) UU No. 1 Tahun 1974 bahwa "Perjanjian tersebut tidak dapat disahkan bilamana melanggar batas-batas hukum, agama, dan kesusilaan". Jadi, setiap perjanjian perkawinan tidak boleh melanggar ketentuan-ketentuan hukum, agama, dan batas-batas kesusilaan dalam masyarakat;

Objek perjanjian perkawinan "selain taklik talak" dapat diketahui dari rumusan ketentuan Undang-Undang No. 1 Th. 1974, Bab VII tentang Harta Benda Dalam Perkawinan, Pasal 35 yang menentukan, bahwa:

1. Harta benda yang diperoleh selama perkawinan menjadi harta bersama;

2. Harta bawaan dari masing-masing suami dan isteri dan harta benda yang diperoleh masing-masing sebagai hadiah atau warisan adalah di bawah penguasaan masing-masing sepanjang para pihak tidak menentukan lain;

Jadi, harta benda dalam perkawinan menurut Pasal 35 UndangUndang No. 1 Th. 1974 adalah sebagai objek perjanjian perkawinan (selain taklik talak), yaitu terdiri dari (i) harta bersama sebagaimana dirumuskan dalam Pasal 35 ayat (1); (ii) harta bawaan atau harta

${ }^{46}$ Perceraian dapat terjadi karena alasan atau alasan-alasan:

a) salah satu pihak berbuat zina atau menjadi pemabuk, pemadat, penjudi dan lain sebagainya yang sukar disembuhkan;

b) salah satu pihak mninggalkan pihak lain selama 2 (dua) tahun berturut-turut tanpa izin pihak lain dan tanpa alasan yang sah atau karena hal lain diluar kemampuannya;

c) salah satu pihak mendapat hukuman penjara 5 (lima) tahun atau hukuman yang lebih berat setelah perkawinan berlangsung;

d) salah satu pihak melakukan kekejaman atau penganiayaan berat yang membahayakan pihak lain;

e) salah satu pihak mendapat cacat badab atau penyakit dengan akibat tidak dapat menjalankan kewajibannya sebagai suami atau isteri;

f) antara suami dan isteri terus menerus terjadi perselisihan dan pertengkaran dan tidak ada harapan akan hidup rukun lagi dalam rumah tangga;

g) Suami menlanggar taklik talak;

h) peralihan agama atau murtad yang menyebabkan terjadinya ketidak rukunan dalam rumah tangga. 
asal dari masing-masing suami dan isteri adalah berada di bawah penguasaan masing-masing suami isteri sebagaimana dirumuskan dalam Pasal 35 ayat (2); (iii) harta masing-masing sebagai hadiah, wasiat, hibah, atau warisan yang diterima suami atau isteri pada masa perkawinan berlangsung dan berada di bawah penguasaan masingmasing suami isteri sebagaimana dirumuskan dalam Pasal 35 ayat (2);

Apabila perkawinan putus, menurut Penjelasan Pasal 35 UndangUndang No. 1 Th. 1974 dijelaskan bahwa apabila perkawinan putus, maka harta bersama tersebut diatur menurut hukumnya masingmasing. Yang dimaksud dengan "hukumnya masing-masing" adalah (i) hukum Adat; (ii) hukum Agama (Islam) bagi orang Islam di Indonesia, antara lain terdapat dalam Kompilasi Hukum Islam; dan (iii) ketentuan hukum yang terdapat dalam KUH Perdata;

Perbuatan hukum yang dapat dilakukan oleh suami dan/atau isteri atas ketiga macam harta benda dalam perkawinan menurut Undang-Undang No. 1 Th. 1974 ditentukan dalam Pasal 36 bahwa:

1. Mengenai harta bersama, suami atau isteri dapat bertindak atas persetujuan kedua belah pihak;

2. Mengenai harta bawaan masing-masing, suami dan isteri mempunyai hak sepenuhnya untuk melakukan perbuatan hukum nengenai harta bendanya.

Berdasarkan ketentuan Pasal 36 ayat (2) Undang-Undang No. 1 Th. 1974, maka yang dimaksud dengan "harta bawaan masingmasing suami isteri" adalah (i) harta bawaan atau harta asal dari suami atau isteri bersangkutan, dan/atau (ii) harta masing-masing suami atau isteri yang diterima atau diperoleh pada masa perkawinan berlangsung melalui warisan, hibah, wasiat, hadiah, atau mahar (sebagai hak isteri menurut hukum Islam);

Dalam Instruksi Presiden Nomor 1 Tahun 1991, tanggal 10 Juni 1991 tentang penyebarluasan Kompilasi Hukum Islam juncto Peraturan Menteri Agama Nomor 154 Tahun 1991, 22 Juli 1991 tentang Pelaksanaan Instruksi Presiden Nomor 1 Tahun 1991, dalam Buku 1 tentang Hukum Perkawinan, Pasal 45 ditentukan bahwa Kedua calon mempelai dapat mengadakan perjanjian perkawinan dalam bentuk:

(1) Taklik talak, dan 
(2) Perjanjian lain yang tidak bertentangan dengan Hukum Islam. ${ }^{47}$

\section{Dampak Transformasi Hukum Perjanjian Perkawinan Pasca Putusan MK No. 69/PUU-XIII/2015}

Secara empiris, perjanjian perkawinan di Indonesia bukan sesuatu yang populer dan dianggap sebuah keharusan. Meski begitu, ada apresiasi yang harus dihaturkan kepada pemerintah sebagai pembentuk Undang-Undang a quo, tetap mengakomodir kebutuhan terkait dengan perjanjian perkawinan. Di satu sisi, adat ketimuran sendiri tidak terlalu mempertimbangkan terkait dengan hal ini. Pembuatan perjanjian perkawinan justru disinyalir sebagai bentuk sifat matrealisitis. Namun disisi yang lain pencantuman perjanjian perkawinan merupakan usaha pemerintah dalam menampung kebutuhan masyarakat dan perkembangan hukum di kemudian hari. ${ }^{48}$

R. Soetojo dan Asis Safioedin mengatakan: pada umumnya perjanjian perkawinan di Indonesia ini dibuat manakala terdapat harta kekayaan yang lebih besar pada suatu pihak daripada pihak lain. Maksud pembuatan perjanjian perkawinan ini adalah untuk mengadakan penyimpangan terhadap ketentuan-ketentuan tentang persatuan harta kekayaan. Para pihak bebas menentukan hukum yang dikehendakinya atas harta kekayaan yang menjadi obyeknya. ${ }^{49}$

Sehingga dengan adanya perjanjian perkawinan tersebut dapat memperjelas status harta masing-masing, apakah termasuk harta bersama, ataukah harta asal. Pada dasarnya hukum Islam tidak secara rinci menjelaskan perjanjian perkawinan, namun lebih pada isyarat tentang kebenaran dan kebolehan mengadakan perjanjian (secara

\footnotetext{
${ }^{47}$ Yang dimaksud dengan "Perjanjian lain" menurut Pasal 47 sampai dengan Pasal 52 KHI adalah:

(1) Perjanjian mengenai Harta Perkawinan sebagaimana ditentukan dalam Pasal 47 sampai dengan Pasal 50KHI;

(2) Perjanjian mengenai tempat kediaman, waktu giliran, dan biaya rumah tangga bagi suami yang melakukan perkawinan dengan isteri kedua, ketiga, atau keempat (Pasal $52 \mathrm{KHI})$;

${ }^{48}$ Syaifullahi Maslul, Putusan Mahkamah Konstitusi Nomor 69/Puu-Xiii/2015 Ditinjau Dari Pemenuhan Hak-Hak Asasi Manusia Dan Asas-Asas Pembentukan Perjanjian, Jurnal Mahkamah IAIM NU Metro, Vol. 1, No. 2, Desember 2016, 409-424

${ }^{49}$ Damanhuri, Segi-Segi Hukum Perjanjian Perkawinan: Harta Bersama (Bandung: Mandar Maju, 2007), 14
} 
universal) selama obyeknya tidak bertentangan dengan hukum Islam serta memiliki unsur manfaat dan nilai kebaikan. Pada perjanjian perkawinan kita dapat menjumpai adanya manfaat dan maslahat dari adanya perjanjian perkawinan bagi pasangan suami istri dan juga manfaat bagi pihak lain.

Ketentuan dalam pasal29UUNo. 1 Th. 1974 tentang Perkawinan, yang khusus mengatur tentang Perjanjian Perkawinan dan Pasal 35 Th. 1974 tentang Perkawinan, yang khusus mengatur tentang Harta Bersama, dimaksudkan oleh pembuat undang-undang agar dapat memberikan kepastian hukum yang berkeadilan kepada para pihak dalam mengarungi mahligai rumah tangga. Pasangan suami isteri yang telah mengikatkan diri ke dalam suatu tali pernikahan, pada perjalanannya tidak sedikit yang berakhir dengan perceraian, karena itu UU mengatur bagaimana melindungi kedua belah pihak khusus yang berkaitan dengan harta benda yang ada pada saat perkawinan maupun harta banda sebagai hasil usaha bersama dalam perkawinan. Bahkan sesungguhnya Perjanjian Perkawinan juga dimaksudkan untuk memberikan perlindungan hukum kepada para pihak ke tiga, yang memiliki hubungan kepentingan dengan harta benda para pihak dalam perkawinan. ${ }^{50}$

Tegasnya, ketentuan yang ada saat ini hanya mengatur perjanjian perkawinan yang dibuat sebelum, pada saat perkawinan dilangsungkan, dan selama perkawinan. Sehingga suami istri yang karena alasan tertentu baru merasakan adanya kebutuhan juga dapat untuk membuat Perjanjian Perkawinan selama ikatan perkawinan. Perjanjian perkawinan ini mulai berlaku antara suami dan isteri sejak perjanjian perkawinan dibuat dan disahkan dengan akta

\footnotetext{
${ }^{50}$ Adapun akibat hukum dari dibuatnya Perjanjian Perkawinan di antaranya adalah:
}

1. Memisahkan harta kekayaan antara pihak suami dengan pihak istri sehingga harta kekayaan mereka tidak bercampur. Oleh karena itu, jika suatu saat mereka bercerai, harta dari masing-masing pihak terlindungi, tidak ada perebutan harta kekayaan bersama atau gono-gini.

2. Atas hutang masing-masing pihak pun yang mereka buat dalam perkawinan mereka, masing-masing akan bertanggung jawab sendiri-sendiri.

3. Jika salah satu pihak ingin menjual harta kekayaan mereka tidak perlu meminta ijin dari pasangannya(suami/istri).

4. Begitu juga dengan fasilitas kredit yang mereka ajukan, tidak lagi harus meminta ijin terlebih dahulu dari pasangan hidupnya (suami/istri) dalam hal menjaminkan aset yang terdaftar atas nama salah satu dari mereka. 
notaris. Isi yang diatur di dalam perjanjian perkawinan tergantung pada kesepakatan pihak-pihak calon suami dan isteri, asal tidak bertentangan dengan Undang-Undang, agama, dan kepatutan atau kesusilaan. Adapun terhadap bentuk dan isi perjanjian perkawinan, kepada kedua belah pihak diberikan kebebasan atau kemerdekaan seluas-luasnya (sesuai dengan asas hukum "kebebasan berkontrak").

Persyaratan untuk sahnya suatu perjanjian apabila dianalisis lebih mendalam sebenarnya sudah tercermin pada syarat perjanjian yang tersebut dalam Pasal $1320 \mathrm{KUH}$ Perdata dan Pasal 45-46 Kompilasi Hukum Islam. Hanya dalam KUHpdt terdapat pemisahan yang cukup tajam antara pelanggaran terhadap persyaratan subyektif dan persyaratan obyektif.

Pelanggaran atau tidak terpenuhinya persyaratan subyektif akan berakibat perjanjian dapat dibatalkan sedangkan pelanggaran terhadap persyaratan obyektif akan berakibat perjanjian batal demi hukum, tetapi dalam fikih Islam pelanggaran terhadap syarat subyektif dan obyektif akan berakibat batalnya perikatan.

Jika perjanjian perkawinan yang telah dibuat suami istri tidak dilaksanakan atau terjadi pelanggaran terhadap perjanjian yang dibuat, maka secara otomatis memberi hak kepada istri untuk meminta pembatalan nikah atau sebagai alasan gugat perceraian, hal ini seperti dinyatakan dalam pasal 51 Kompilasi Hukum Islam. ${ }^{51}$

Upaya untuk mempertahankan perjanjian perkawinan yang telah disahkan merupakan bagian hak bagi semua pihak yang berjanji. Perkara tentang sengketa perjanjian perkawinan harus diselesaikan oleh penegak hukum yang berwenang.

Perjanjian taklik talak yang telah melembaga di Indonesia, bukan hanya dilihat dari sudut pandang suatu peraturan yang mengandung nilai dasar manfaat, keadilan dan kepastian hukum, tetapi mengandung nilai yang sifatnya transendental berupa hikmah.

\section{Teori Mashlahah Mursalah dalam Perjanjian Perkawinan}

Ulama yang berhujjah dengan mashlahah mursalah bersikap hatihati sehingga tidak menimbulkan pembentukan hukum berdasarkan hawa nafsu dan keinginan tertentu. Oleh karena itu mereka

${ }^{51}$ Pelanggaran atas perjanjian perkawinan memeberihak kepada isteri untuk memeinta pembatalan nikah atau mengajukannya. Sebagai alasan gugatan perceraian ke Pengadilan Agama. 
menyusun tiga syarat pada penerapan mashlahah mursalah yang dipakai sebagai dasar pembentukan hukum, yaitu: ${ }^{52}$

Pertama: harus merupakan kemashlahatan yang hakiki, bukan yang bersifat dugaan. Maksudnya untuk membuktikan bahwa pembentukan hukum pada suatu kasus dapat mendatangkan kemanfaatan dan penolakan bahaya. Jika sekedar dugaan bahwa pembentukan hukum dapat menarik manfaat tanpa mempertimbangkannya dengan bahaya yang mungkin datang, maka kemashlahatan ini bersifat dugaan semata (mashlahah wahmiyyah). Contohnya, pencabutan hak Suami untuk mentalak Istrinya dan menjadikan hak talak tersebut sebagai hak Hakim dalam segala situasi dan kondisi.

Kedua: Kemashlahatan tersebut bersifat umum, bukan pribadi. Maksudnya untuk membuktikan bahwa pembentukan hukum pada suatu kasus dapat mendatangkan manfaat bagi mayoritas umat manusia, atau menolak bahaya dari mereka dan bukan untuk kemashlahatan individu atau beberapa orang. Hukum tidak boleh disyariatkan untuk mewujudkan kemashlahatan khusus bagi penguasa atau pembesar, dengan memalingkan perhatian dan kemashlahatan mayoritas umat. Dengan kata lain seluruh kemashlahatan harus memberikan manfaat untuk umat manusia.

Ketiga: Pembentukan hukum berdasarkan kemashlahatan dan tidak bertentangan dengan hukum atau prinsip yang berdasarkan nash atau ijma'. Oleh karena itu tidak benar jika mengakui kemashlahatan yang menuntut persamaan anak laki-laki dan perempuan dalam pembagian warisan. Sebab mashlahah yang demikian itu batal, karena bertentangan dengan nash dalam Al-Qur'an.

Adapun adanya perjanjian perkawinan adalah untuk mengantisipasi kemungkinan terjadinya tindakan tidak adil suami terhadap isteri-isteri dan anak-anaknya, serta sebaliknya. Maka adanya legalitas perjanjian perkawinan merupakan upaya hukum yang meskipun kelihatannya bersifat administratif, ia memiliki fungsi جَلْب المصنَالِح soal preventif yang sangat besar. Seperti dalam kaidah

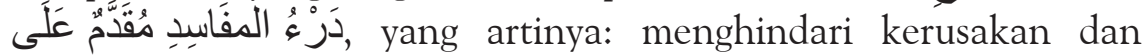
kemudlaratan didahulukan daripada memperoleh kemashlahatan.

${ }^{52}$ Abdul Wahab Khallaf, Ilmu Ushul Fiqih, 145. 
Secara metodologis, ketentuan tentang perjanjian perkawinan sesuai dengan dalil mashlahah mursalah. Karena dapat menampung kebutuhan masyarakat dan perkembangan hukum di kemudian hari..$^{53}$ Selain itu juga dapat memberikan kepastian hukum yang berkeadilan kepada para pihak dalam rumah tangga, sehingga dapat melindungi kedua belah pihak khusus yang berkaitan dengan harta benda yang ada pada saat perkawinan maupun harta banda sebagai hasil usaha bersama dalam perkawinan. Bahkan perjanjian perkawinan juga dimaksudkan untuk memberikan perlindungan hukum kepada para pihak ketiga, yang memiliki hubungan kepentingan dengan harta benda para pihak dalam perkawinan.

Begitu pula dalam perkawinan campuran, dengan perkawinan tersebut maka terjadi percampuran harta persatuan bulat, sehingga harta yang diperoleh suami sebelum dan sepanjang perkawinan demi hukum menjadi harta isteri, demikian pula sebaliknya, sehingga seluruh harta yang dimiliki menjadi harta bersama sesuai dengan Pasal 21 ayat (3) UUPA..$^{54}$ Jika tidak terjadi pemisahan harta dalam perjanjian perkawinan, maka pada akhirnya WNI akan kehilangan haknya untuk memiliki hak milik dan hak guna bangunan.

Dalam Undang-Undang No. 1 Th. 1974 tentang Perkawinan menegaskan bahwa kedudukan suami-istri dalam perkawinan adalah seimbang, dan dalam Pasal 31 ayat (2) dikatakan masing-masing pihak berhak untuk melakukan perbuatan hukum. Jadi, dalam perkawinan para pihak berhak melakukan tindakan hukum berdasarkan norma Pasal 31 ayat (2) dari Undang-Undang Perkawinan.

Jadi jelas bahwa pembentukan hukum pada mashlahah mursalah adalah suatu kebenaran, dan jika pintu tersebut tidak dibuka, maka akan terjadi stagnasi pembentukan hukum Islam, dan hukum Islam akan berhenti tidak bisa mengikuti perkembangan situasi, kondisi dan zaman. Dengan syarat, dasar pembentukan hukum dalam mashlahah mursalah memenuhi tiga hal yaitu kemashlahatan harus bersifat umum, harus hakiki dan tidak bertentangan dengan nash syar'i maupun prinsip syar'i yang lainnya..$^{55}$

${ }^{53}$ Ahmad Rofiq, Pembaharuan Hukum Islam di Indonesia (Yogyakarta: Gama Media, 2001), 111 .

${ }^{54}$ Orang asing yang sesudah berlakunya Undang-undang ini memperoleh hak milik karena percampuran harta karena perkawinan

${ }^{55}$ Abdul Wahab Khallaf, Ilmu Ushul Fiqih, 147. 


\section{PENUTUP}

Perkawinan dalam Hukum Islam merupakan perjanjian yang kuat (mitsaqan ghalidzan) untuk mentaati perintah Allah dan melakukannya merupakan ibadah. Maka perkawinan itu sendiri merupakan suatu perjanjian yang mengikat kedua belah pihak. Sedangkan dalam peraturan perundang-Undangan di Indonesia, perjanjian perkawinan diatur dalam pasal 29 UU No. 1 Th. 1974 tentang perkawinan, yang implementasinya dilaksanakan dalam pasal 2 Peraturan Menteri Agama No. 3 Th. 1975 dan pasal 45-52 KHI dan pasal $1320 \mathrm{KUH}$ Perdata.

Eksistensi perjanjian perkawinan pasca putusan MK No. 69/ PUU-XIII/2015, merupakan langkah progresif khususnya bagi Undang-Undang Hukum Keluarga di Indonesia. yaitu dalam rangka menjaga hak-hak asasi manusia dan hak-hak konstitusional warga negara. Perjanjian perkawinan tidak lagi hanya bisa dibuat sebelum atau ketika perkawinan dilangsungkan, tetapi juga selama ikatan perkawinan kedua belah pihak atas persetujuan bersama dapat mengajukan perjanjian tertulis yang disahkan oleh pegawai pencatat perkawinan atau notaris.

Adanya formulasi hukum dalam perjanjian perkawinan pasca putusan MK sejalan dengan teori mashlahah mursalah yang mana dibuatnya perjanjian perkawinan tersebut merupakan upaya hukum untuk mengikuti perkembangan situasi, kondisi dan zaman. Dengan syarat, dasar pembentukannya memenuhi tiga hal yaitu kemashlahatan harus bersifat umum, harus hakiki dan tidak bertentangan dengan nash syar'i maupun peraturan perundangundangan yang berlaku. Dengan adanya perjanjian perkawinan diharapkan sebagai bentuk antisipasi untuk meminimalisir konflik atau permasalahan yang terjadi ke depannya karena telah jelas kedudukan hukumnya masing-masing. Terutama terkait harta sebagai salah satu sumber utama pemicu konflik dalam kehidupan berumah tangga. 


\section{DAFTAR RUJUKAN}

Abdurrahman. 1995. Kompilasi Hukum Islam di Indonesia. Jakarta: Akademika Pressindo.

Ali, Zainuddin. 2009. Hukum Perdata Islam Di Indonesia. Jakarta: Sinar Grafika, cet III

Al-Mashri, Mahmud. 2011. Bekal Pernikahan. Jakarta: Qisthi Perss

Amin, Ma'ruf dkk. 2011. Himpunan Fatwa MUI Sejak 1975. Jakarta: Erlangga

Andasasmita, Komar. 1990. Notaris II Contoh Akta Otentik dan Penjelasannya, ctk. Kedua. Bandung: Ikatan Notaris Indonesia (INI) Daerah Jawa Barat.

Anwar, Syamsul. 2010. Hukum Perjanjian Syariah Studi Teori akad dalam Fikih Muamalah, Jakarta: PT Raja Grafindo Persada

Arikunto, Suharsimi. 1998.Prosedur Penelitian Suatu Pendekatan Praktik. Jakarta: Rineka Cipta.

Hadi, Sutriono. 1984.Metodologi Research Yogyakarta: Yayasan Penerbitan Fakultas Psikolog UGM.

Kansil, CST. 1991. Hukum Perdata I. Pradnya Paramita.

Meliala, Djaja S. 2014. Hukum Perdata dalam Perspektif BW. Bandung: Nuansa Aulia.

Muhammad, Abdulkadir. 2010. Hukum Perdata Indonesia. Bandung: PT. Citra Aditya Bakti.

Nuruddin, Amiur dan Azhari Akmal Tarigan. 2004. Hukum Perdata Islam di Indonesia. Jakarta: Prenada Media.

Rofiq, Ahmad. 2013. Hukum Perdata Islam di Indonesia. Jakarta: RajaGrafindo Persada.

Subekti, R. 2003. Pokok-Pokok Hukum Perdata. Jakarta: Intermasa.

.............. 1999. Kitab Undang-Undang Hukum Perdata. Jakarta: Pradnya Paramita. 
Triwulan, Tutik. 2008. Hukum Perdata dalam Sistem Hukum Nasional. Jakarta: Kencana.

Mahmood, Tahir. 1987. Personal Law in Islamic Countries. New Delhi: Times Press

Mauliadi, Herry. 2005.Analisis Hukum Terhadap Perjanjian Perkawinan, Banjarmasin: Antasari Press.

Mualim, Amir dan Yusdani. 2001.Konfigurasi Pemikiran Hukum Islam, Yogyakarta: UII Press.

Sabiq, Sayid, tt, Fiqh Sunnah. Mesir: Syirkah dar al-Kiblah al Saqafiyah al-Islamiyah, Juz II

Shihab, M.Quraish, 2004, Tafsir Al-Mishbah. Jakarta: Lentera Hati,Vol 2

Shahrur, Muhammad. 2004. Metodologi Fiqih Islam Kontemporer, Yogyakarta: eLSAQ Press, Cet II

Sya'ban, Zakiyuddin. 1967. al-Ahkam al-Syar'iyah li af-Ahwal alSyakhsiyah. Mesir: al-Nahdah al-Arabiyah

Syarifudddin, Amir. 2014. Hukum Perkawinan Islam di Indonesia. Jakarta: Kencana.

Subekti, R. 1982. Hukum Perjanjian. Jakarta: Intermassa

Suyasubrata, Sumadi. 1989. Metodologi Penelitian, Jakarta: CV Rajawali Press.

Soekanto, Soerjono. 2007. Pengantar Penelitian Hukum. Jakarta: Universitas Indonesia Press

Zuhaili, Wahbah. 1989. al-Figh al-Islamy wa Adillatuh. Mesir: Dar alFikr, Jilid IV. Cet.III

\section{Peraturan Perundang-Undangan}

Inpres tahun 1991 tentang Kompilasi Hukum Islam (KHI)

Kitab Undang-Undang Hukum Perdata Buku ketiga tentang Perikatan

Putusan MK No. 69/PUU-XIII/2015

UU No. 1 Tahun 1974 tentang Perkawinan 
180 | Mamba'ul Ngadhimah, Lia Noviana dan Ika Rusdiana

UU No. 9 Tahun 1975 tentang Pelaksanaan UU No. 1 Tahun 1974 tentang Perkawinan

UU No. 35 Tahun 2014 tentang Perubahan UU No. 23 Tahun 2002 tentang Perlindungan Anak 